\title{
MAGNETIC METHOD FOR MEASURING THE THICKNESS OF NONMAGNETIC COATINGS ON IRON AND STEEL
}

\author{
By Abner Brenner
}

\section{ABSTRACT}

A nondestructive, magnetic method is described for measuring the thickness of nonmagnetic coatings on steel. The instrument used is similar to that previously described for measuring nickel coatings on nonmagnetic base metals. The present method depends on the decrease in the attraction of a permanent magnet for steel when the two are separated by a nonmagnetic coating.

Measurements on commercial coatings of which the actual thicknesses were determined by standard methods yielded results that were accurate to \pm 10 percent for most coatings. The results were about 25 percent low for hot-dipped tin coatings, which are only about 0.0001 in. thick.

Because nickel is less magnetic than steel, the thickness of nickel coatings on steel can be measured by this method, using a suitable calibration curve.

\section{CONTENTS}

I. Introduction $\ldots \ldots$

II. Principles involved

III. Types of instruments

IV. Spring balance

1. Design

2. Magnet..... 360

3. Procedure $\ldots \ldots \ldots \ldots \ldots \ldots \ldots$

4. Calibration

V. Factors affecting precision and accuracy

1. Smoothness of surface $\ldots$

2. Curvature of surface

3 . Thickness of base metal

4. Magnetic properties of base metal

5. Magnetic properties of coatings _...

VI. Typical results

VII. Conclusions_._.

\section{INTRODUCTION}

During recent years, the interest in tests for the thickness of metallic coatings has been increased by the adoption of specifications for plated coatings. Most methods of testing destroy the coating and sometimes the whole specimen. It is desirable to have nondestructive methods which will permit the testing of a larger number of specimens without increased cost. Such methods will be useful especially for plant control.

In a previous publication, ${ }^{1}$ a nondestructive magnetic method was described for measuring the thickness of nickel coatings on nonmagnetic base metals, such as copper or brass. The present work is

\footnotetext{
1 J. Research NBS 18, 565 (1937) RP994.
} 
an extension of magnetic methods to the testing of nonmagnetic coatings upon steel.

Methods for the latter purpose have received attention during the last few years, and several papers on this subject appeared while this research was in progress. The purpose of this paper is to describe a simple, compact, magnetic instrument for such measurements and to discuss the accuracy of the method.

\section{PRINCIPLES INVOLVED}

The method for measuring the thickness of nickel plating on brass depends on the magnitude of the attractive force between a magnet and the nickel coating. The method to be described for the measurement of nonmagnetic coatings on steel depends on the decrease in magnetic attraction caused by the presence of a nonmagnetic coating between a magnet and the steel base metal.

The maximum attractive force between a magnet and steel is obtained when the two are in contact. Any nonmagnetic material, such as zinc, copper, enamel, paint, or an air gap, placed between the magnet and the steel, decreases the magnetic attraction to an extent that depends upon the thickness of the intervening layer. If a device with a permanent bar magnet is calibrated with nonmagnetic coatings of known thickness on steel, it can be used to determine the thicknesses of other nonmagnetic coatings. The measurement consists in bringing the end of the magnet into contact with the coating on the steel and determining the force necessary to detach the magnet. The thickness is read off from the appropriate calibration curve, on which the decrease in the detaching force is plotted against the thickness.

\section{TYPES OF INSTRUMENTS}

For measuring the attractive forces involved, any instrument can be used which will measure a force of several grams with an error of not more than 1 percent. An ordinary analytical balance may be used. Recently, W. E. Hoare and B. C. Chalmers ${ }^{2}$ described a device in which a permanent magnet is attached to one arm of an improvised lever balance. The detaching force is measured in terms of the weight (or volume) of water which is introduced into a graduated cylinder attached to the other arm. This instrument was used for measuring the thickness of coatings on tin plate.

For similar measurements, I. V. Radtchenko and F. K. Shestakovsky ${ }^{3}$ used a magnet suspended from a galvanometer needle, the attractive force being measued in terms of the current through the galvanometer that was required to detach the magnet from the coating.

The General Electric Co. ${ }^{4}$ manufactures an electric gage with which the thickness of a coating is measured by the reluctance of a magnetic circuit passing from a coil in the gage head, to the steel base, through the coating. This instrument measures thickness in terms of an electric current instead of an attractive force. It is useful chiefly for measuring coatings at least several thousandths of an inch thick, such as vitreous enamels, and has not been adapted to plated coatings,

J. Sci. Instr. 14, 248 (1937).

3 J. Tech. Phys. U. S. S. R. 5, 1372 (1935).

Instruments 8, 341 (1935); Enamelist, p. 9.(Nov. 1936). 


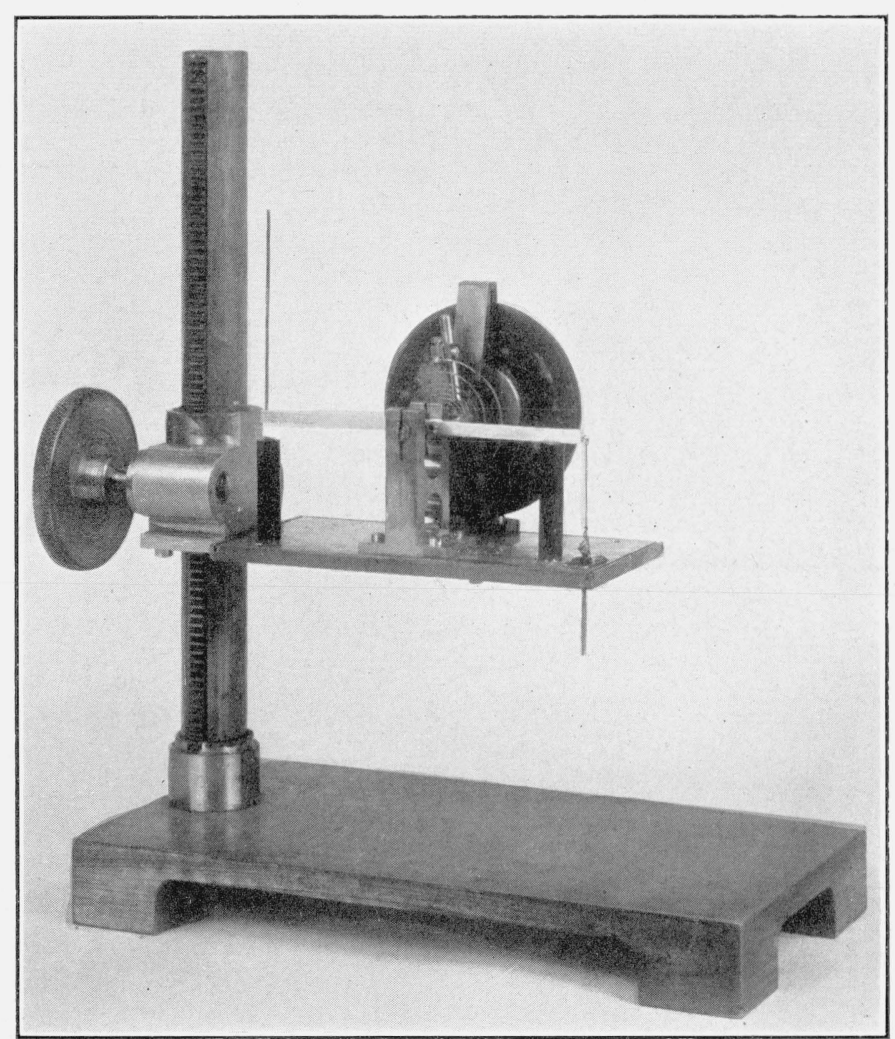

FiguRE 1.-Spring balance with cover and false bottom removed. 
which are usually less than one thousandth of an inch thick. One disadvantage of this gage, as designed, is that it can be used only on plane surfaces. Recently, W. H. Tait ${ }^{5}$ described an instrument that is similar in principle to the General Electric gage, and used it for measuring the thickness of thin coatings, such as those on tin plate.

\section{SPRING BALANCE}

\section{DESIGN}

A spring balance, figure 1, may be used for measuring the thickness of nonmagnetic coatings on steel. The instrument is of the same

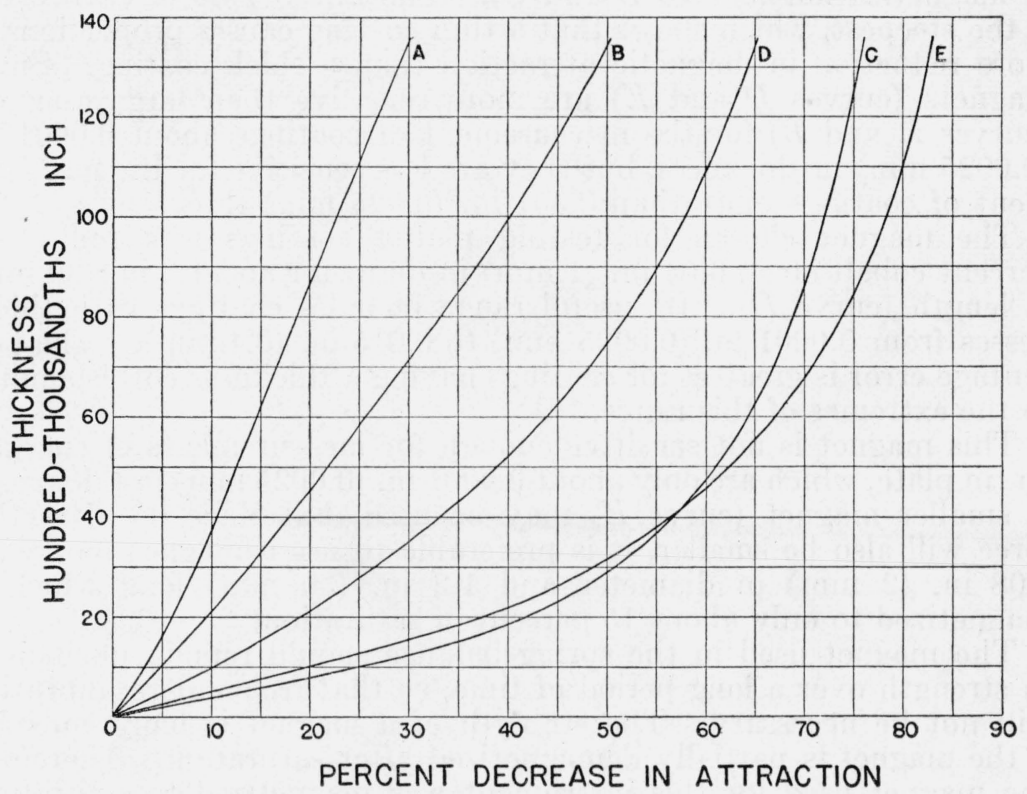

FIGURE 2.-Percentage decrease in the attraction of various magnets for mild steel, caused by the interposition of nonmagnetic coatings

\begin{tabular}{|c|c|c|c|c|c|c|}
\hline \multirow{2}{*}{ Curve } & \multicolumn{4}{|c|}{ Magnet } & \multirow{2}{*}{$\begin{array}{c}\text { Magnetic } \\
\text { satura- } \\
\text { tion }\end{array}$} & \multirow{2}{*}{$\begin{array}{l}\text { Attrac- } \\
\text { tive force } \\
\text { for un- } \\
\text { coated } \\
\text { steel }\end{array}$} \\
\hline & \multicolumn{2}{|c|}{ Diameter } & \multicolumn{2}{|c|}{ Length } & & \\
\hline $\begin{array}{l}A \\
B \\
B \\
B\end{array}$ & $\begin{array}{c}\text { in. } \\
0.2 \\
.08 \\
.08 \\
.04 \\
.03\end{array}$ & $\begin{array}{l}\mathrm{mm} \\
5 \\
2 \\
2 \\
1 \\
\quad .75\end{array}$ & $\begin{array}{l}\text { in. } \\
6 \\
1.2 \\
1.2 \\
1.2 \\
1.2\end{array}$ & $\begin{array}{r}\mathrm{mm}_{150} \\
30 \\
30 \\
30 \\
30\end{array}$ & $\begin{array}{r}\text { Percent } \\
100 \\
100 \\
15 \\
80 \\
100\end{array}$ & $\begin{array}{r}\text { g } \\
270 \\
41 \\
6 \\
6 \\
\quad 2.5\end{array}$ \\
\hline
\end{tabular}

type as that described for measuring the thickness of nickel coatings on nonmagnetic base metals. ${ }^{6}$ The principal differences are that in the present instrument the magnet is smaller and the spring stronger.

\footnotetext{
J. Sci. Instr. 14, 341 (Oct. 1937).

J. Research NBS 18, 565 (1937) RP994.
} 
The magnet is freely suspended from one end of a horizontal Duralumin lever arm, which carries a vertical brass needle for indicating the position of the magnet. The magnet slides through a glass bead which prevents sidewise movement. The end of the magnet is hemispherical and polished.

\section{MAGNET}

The choice of a magnet is somewhat arbitrary and depends on the range of thicknesses to be measured. Curves for the decrease in attractive force against thickness of coating for magnets of various sizes are shown in figure 2. The shape of the curve depends on both the dimensions of the magnet (curves $A, B, D$, and $E$ ) and its degree of magnetization (curves $B$ and $C$ ). The initial part of each curve is the steepest, which shows that a thin coating causes proportionally more reduction in magnetic attraction than a thick coating. Small magnets (curves $D$ and $E$ ) are more sensitive than large magnets (curves $A$ and $B$ ) for the measurement of coatings about 0.0001 in. $(0.0025 \mathrm{~mm})$ in thickness, but they are less sensitive for the measurement of coatings more than 0.001 in. $(0.025 \mathrm{~mm})$ thick.

The magnet chosen for testing plated coatings is a rod of 36 percent cobalt steel, 0.04 in. ( $1 \mathrm{~mm}$ ) in diameter and 1.2 in. (30 mm) in length (curve $D$ ). Its useful range includes coatings with thicknesses from 0.0001 in. $(0.0025 \mathrm{~mm})$ to $0.015 \mathrm{in}$. $(0.4 \mathrm{~mm})$. The percentage error is greatest for coatings having a thickness corresponding to the extremes of this range.

This magnet is not sensitive enough for measurements of coatings on tin plate, which are only about 0.0001 in. $(0.0025 \mathrm{~mm})$ in thickness. A smaller magnet (curve $E$ ) may be used, but since its attractive force will also be smaller, it is preferable to use a magnet (curve $C$ ) 0.08 in. $(2 \mathrm{~mm})$ in diameter and $1.2 \mathrm{in}$. $(30 \mathrm{~mm})$ long which is magnetized to only about 15 percent of saturation.

The magnet used in the spring balance should remain unchanged in strength over a long period of time, so that frequent recalibration will not be necessary. The strength of a magnet is more constant if the magnet is partially demagnetized after saturation. Therefore, the magnet used for this instrument was magnetized to saturation, and then demagnetized to about 80 percent of saturation, by bringing a larger magnet near it. A magnet so treated retains its strength indefinitely provided that only the end comes into contact with steel. However, if the magnet is stroked from the center towards the end, or vice versa, with a piece of steel, its strength is decreased. By continued stroking, the strength of small magnets may be reduced to 40 percent of saturation. Loss of magnetism by accidental contact of the shaft of the magnet with steel is prevented by encasing the magnet in a glass tube with thin walls (0.02 in. or $0.5 \mathrm{~mm}$ thick) so that the end projects only a very short distance beyond the end of the tube.

The instrument, as developed, has several advantages over the types previously described. The advantages of an instrument employing a permanent magnet over the electrical devices are that (1) measurements with the former are scarcely influenced by the curvature of a surface, and (2) it measures the thickness of coating at a

\footnotetext{
'Much of the commercial tin plate has about $2 \mathrm{lb}$ of tin per base box. Each "pound per base box" corresponds to a thickness of about 0.00006 in. $(0.0015 \mathrm{~mm})$ of tin.
} 
point rather than over an area. The present design of instrument is simpler, more compact and more rugged than those previously described that also employed a permanent magnet.

\section{PROCEDURE}

Measurements with the instrument are made by bringing the end of the magnet into contact with the coating and then turning the dial until the magnet is detached. The first reading is approximate and several more readings should be taken and averaged. The dial should be turned quite slowly in the neighborhood of the point of detachment of the magnet. Dial readings are converted to thicknesses by means of a calibration curve, or the dial may be graduated to read thicknesses directly.

The test specimen should be placed normal to the magnet. Measurements with a freely suspended magnet, as used in the present instrument, are not appreciably affected if the angle of contact varies a degree or two from 90 degrees; but if the magnet were rigidly attached to the lever arm, each degree variation from the normal would produce an error of more than 3 percent.

Occasionally the end of the magnet picks up small magnetic particles which prevent contact of the magnet and specimen and cause low, nonreproducible readings. Such particles should be brushed from the end with a camel's-hair brush.

\section{CALIBRATION}

Zinc coatings of known thickness were used for calibrating the instrument over the thickness range of 0 to 0.0015 in $(0.04 \mathrm{~mm})$. These specimens were plated to a uniform thickness by the method described in a previous publication. ${ }^{8}$ Still thicker coatings for calibration were obtained by gluing glazed paper of known thickness to sheet steel, care being taken to press out the excess of adhesive. In order to check the thickness of the paper layer, the thickness of the sheet was measured with a micrometer before and after the paper was applied. 'This method is not accurate for layers less than several thousandths of an inch in thickness.

The calibration is best represented by a curve such as shown in figure 4. The dial of the instrument, which is graduated into 100 divisions, is set to read 100 when the instrument is balanced in the absence of any magnetic material. The spring is so selected that the dial reads close to 0 when the magnet is detached from bare steel. By this method of setting the dial, low scale readings correspond to thin coatings and high readings to thick coatings.

\section{FACTORS AFFECTING PRECISION AND ACCURACY}

The factors that affect the precision and accuracy of the method are:

1. The smoothness of the surface.

2. Curvature of the surface.

3. Thickness of the base metal.

4. Magnetic properties of the base metal.

5. Magnetic properties of the coatings.

8 J. Research NBS 18, 565 (1937) R P994. 


\section{SMOOTHNESS OF THE SURFACE}

Lack of smoothness of the steel base metal or coating is one of the chief sources of inaccuracy with this method, and is more likely to cause errors than are differences in the magnetic properties of the steels. Occasionally it is necessary to test bare steel for the purpose of comparing it with the standard steel. Reproducible readings on bare steel can be obtained only if the surface is smooth and free from imperfections. Some cold-rolled steel has a sufficiently smooth surface, but, in general, the surface of steel must be polished before testing, either by buffing or, if the surface is too rough, by use of successively finer polishing papers. Polished steel surfaces give readings reproducible to about 1 percent, while readings on rough surfaces are erratic.

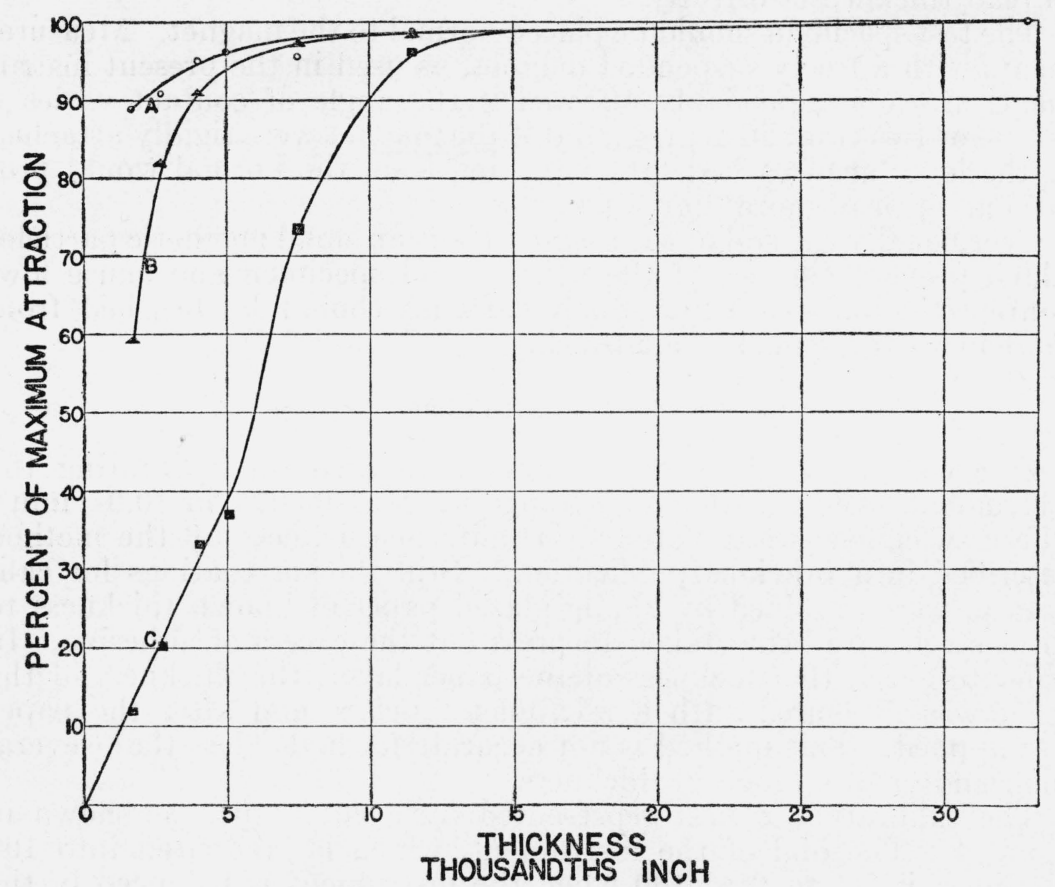

FIGURE 3.-Attractive force of magnets for various thicknesses of sheet steel, expressed as percentage of the maximum force obtainable on steel

\begin{tabular}{|c|c|c|c|c|}
\hline \multirow{2}{*}{ Curve } & \multicolumn{4}{|c|}{ Magnet } \\
\hline & \multicolumn{2}{|c|}{ Diameter } & \multicolumn{2}{|c|}{ Length } \\
\hline $\begin{array}{l}A \\
B \\
C\end{array}$ & $\begin{array}{c}\text { in. } \\
0.04 \\
.08 \\
.20\end{array}$ & $\begin{array}{c}m m \\
1 \\
2 \\
5\end{array}$ & $\begin{array}{l}\text { in. } \\
1.2 \\
1.2 \\
6.0\end{array}$ & $\begin{array}{r}m m \\
30 \\
30 \\
150\end{array}$ \\
\hline
\end{tabular}

The effect of roughness of the base metal or coatings on the accuracy is most pronounced with coatings less than 0.001 in. $(0.025 \mathrm{~mm})$ thick. The smoothness of the coating is even more important than 
that of the base metal; in fact the reproducibility of readings is fairly good on smooth coatings even though they are produced on a rough base metal. For example, fairly reliable readings are obtained on galvanized zinc surfaces (which are wiped smooth in the manufacturing process), even though the base metal may have been severely etched prior to galvanizing.

It was found that more reproducible and accurate measurements on rough coatings can be obtained if the coating is burnished at the point to be tested, just enough to produce a smooth area about 0.1 in. $(3 \mathrm{~mm})$ in diameter. A suitable tool for the purpose consists of a $0.5 \mathrm{in}$. $(1.3 \mathrm{~cm})$ ball bearing soldered to a rod. A drop of oil is applied before burnishing. It is necessary to use burnishing only if the readings on a surface are not reproducible. It may be used with advantage on rough or coarsely crystalline coatings of zinc, cadmium, or copper, but is unnecessary on galvanized sheet, terne plate, or tin plate, or on any coatings more than 0.001 in. $(0.025 \mathrm{~mm})$ thick.

\section{CURVATURE OF THE SURFACE}

Magnetic measurements with a magnet $0.04 \mathrm{in} .(1 \mathrm{~mm})$ in diameter are not affected very much by curvature. No appreciable error is involved in measurements on cylindrical rods more than 0.125 in. $(3 \mathrm{~mm})$, or on spheres more than 0.5 in. $(13 \mathrm{~mm})$ in diameter. Measurements are not affected by the proximity of an edge, if the magnet is at least 0.08 in. $(2 \mathrm{~mm})$ from it.

\section{THICKNESS OF THE BASE METAL}

The curves in figure 3 show that the thickness of the base metal does not affect the accuracy of measurements made with a 0.04 -in. (1-mm) magnet if the base metal is more than 0.01 in. $(0.25 \mathrm{~mm})$ thick. The attractive force between very thin sheet steel (less than 0.005 in. thick) and the largest magnet used (curve C) is almost proportional to the thickness of the sheet (which relation also exists with thin layers of nickel).

\section{MAGNETIC PROPERTIES OF THE BASE METAL}

The nature of the ferrous base metal affects magnetic measurements, and separate calibrations should be made for metals which vary by more than about 5 percent in magnetic properties (as measured by their magnetic attraction). The attractive forces between a small magnet and many different specimens of mild steel, such as are used in stamping and forming operations, were determined and found not to vary more than a few percent. Hence, with one calibration, measurements can be made on the majority of plated iron or steel products. Figure 4 illustrates calibration curves for several ferrous metals. Curve $A$ was drawn through points for zinc coatings on various steels. All these points are within \pm 4 percent of the average curve. Coatings on malleable cast iron would also be represented by this curve.

Certain high-carbon steels, and also gray cast iron, require separate calibrations. Gray cast iron (curve $B$ ) is attracted by the magnet with only about 90 percent of the force exerted by mild steel. How- 
ever, the curve approaches that for mild steels (curve $A$ ) at about 0.001 in. $(0.025 \mathrm{~mm})$. Hence, for coatings thicker than 0.001 in., the calibration curve for mild steels will serve for practically any ferrous metal. Curve $C$ is an extension (on a different scale) of curve $A$ to thicker coatings. From 0.001 in. on, it agrees with the curve for cast iron within about one-half scale division.

Whether or not coatings on a given ferrous metal will fit a certain calibration curve can be determined by taking a reading on the uncoated metal (suitably polished). If the attractive force of a particular metal does not vary by more than two scale divisions

4\%

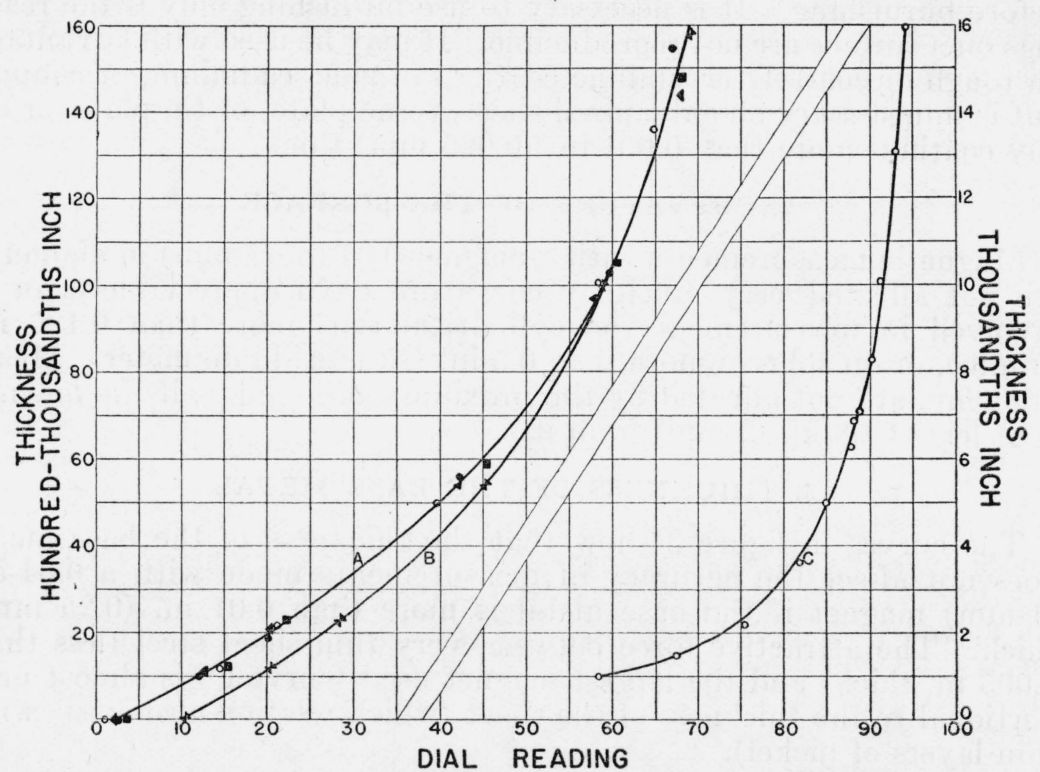

Figure 4.-Calibration curves for various ferrous base metals

Curve $A$ is an average curve for the following steel base metals:

$\mathrm{O}=$ Cold-rolled steel, 0.033 inch thick.

$\nabla=$ Sheet steel, 0.012 inch thick.

圈=Spring steel, 0.15 inch thick.

$=$ Drill rod, 0.25 inch in diameter.

Curve $C$ is an extension of curve $A$ (on a different scale) to thicker coatings.

Curve $B$ is the calibration curve for gray cast iron, 0.15 inch thick.

from that of the steel used for calibration, the error involved in the measurement of coatings thicker than 0.0001 in. $(0.0025 \mathrm{~mm})$ will not be significant. However, if the reading on the base metal varies by more than this amount, a correction should be applied to the dial readings obtained on coatings that are thinner than about 0.0005 in. $(0.013 \mathrm{~mm})$. This correction is made by adding to or subtracting from the dial reading $F$, a quantity equal to $D(1-T)$, where $D$ is the difference (in scale divisions) between the initial reading on the standard steel and on the uncoated specimen, and $T$ is the thickness of coating in 1/1000 in. For example, if a sample of iron gave an initial reading of plus 4 divisions $(D)$, while that on the standard steel was 0 , and, with a coating approximately 0.0003 in. thick, the dial reading, $F$, was 35 , the latter should be corrected as follows:

$$
F_{1}=F-D(1-T)=35-4(1-0.3)=32.2
$$


The thickness should then be read from the standard calibration curve at the point corresponding to 32.2 divisions and not 35 divisions. It will be noted that when $T=1$, i. e., 0.001 in., the correction becomes 0 .

If a metal differs by more than 5 divisions (or about 5 percent) from the standard steel, it is preferable to make a separate calibration curve for coatings on that metal, rather than to apply a correction for thin coatings.

\section{MAGNETIC PROPERTIES OF COATINGS}

Thus far, the discussion has been confined to measurements of nonmagnetic coatings. Measurements can be made also of magnetic nickel coatings on steel because with the magnets used the nickel exerts only about one-half as much attraction as does the steel. A separate calibration is required for nickel coatings. The curves given in figure 5 (to be compared with fig. 4) show that the interposition of nickel coatings does not decrease the attraction of the magnet for the steel as much as do corresponding nonmagnetic coatings. Hence, measurements of nickel coatings on steel may be expected to be less accurate than measurements of nonmagnetic coatings. There is a compensating factor, however. Most nickel coatings are deposited over a smooth steel surface and are themselves polished, so that more reproducible readings are obtained. Nickel coatings much over 0.001 in. $(0.025 \mathrm{~mm})$ in thickness cannot be measured magnetically because beyond that range of thickness the attractive force changes too slowly with the thickness. The calibration curve for nickel should be checked more frequently than the one for nonmagnetic coatings, be-

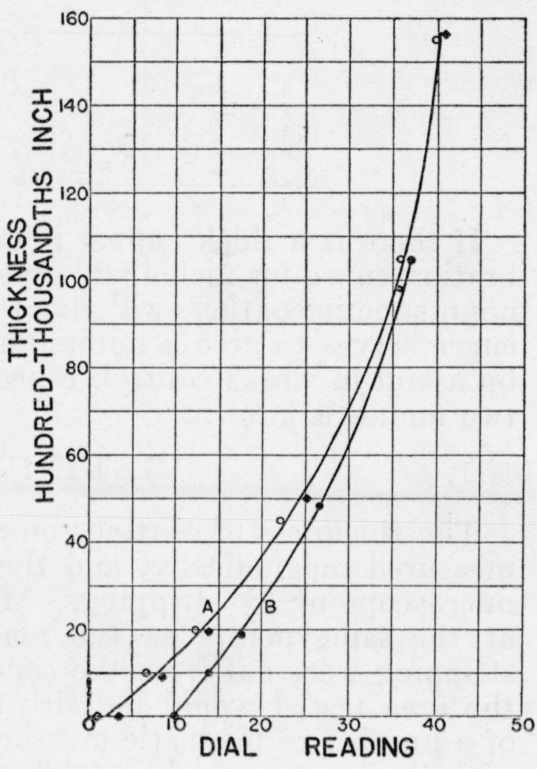

Figure 5.-Calibration curves for nickel coatings on ferrous base metals.

Curve $A$ is an average curve for the following steels: $O=$ Cold-rolled steel, 0.033 inch thick.

$\quad=$ Spring steel, 0.15 inch thick.
Curv $_{\theta} B$ is for gray cast iron, 0.15 inch thick. cause a small error in the dial reading produces a larger error in determining the thickness of nickel than of nonmagnetic coatings.

The variation in the magnetic properties of nickel coatings will not have much effect on the accuracy of measurement. Nickel deposited from a "single salt" bath operated at a high $\mathrm{pH}(5.9)$ is only 40 percent as magnetic (according to its attractive force for a small magnet) as nickel deposited under ordinary conditions. Magnetic tests of coatings 0.0005 and 0.001 in. thick, deposited under the above conditions on steel, gave results about 10 and 25 percent too high, respectively. In commercial plating, the variation in the magnetic prop- 
erties of nickel is less than half of that represented by the above specimens and hence should not cause errors greater than about 10 percent in the magnetic measurement of thickness.

Composite coatings of nickel and copper can be measured magnetically only if the copper layer is less than 10 percent of the total. The accuracy of measurements on nickel coatings plated over a copper flash is shown in table 1.

TABLE 1.-Thickness of composite copper-nickel coatings

[Thickness of coating in hundred-thousandths in.]

\begin{tabular}{|c|c|c|c|c|}
\hline Copper & Nickel & Total & $\begin{array}{l}\text { Total by } \\
\text { magnetic } \\
\text { method }\end{array}$ & Error \\
\hline $\begin{array}{l}3 \\
7 \\
4 \\
8\end{array}$ & $\begin{array}{r}54 \\
54 \\
115 \\
113\end{array}$ & $\begin{array}{r}57 \\
61 \\
119 \\
121\end{array}$ & $\begin{array}{r}60 \\
69 \\
126 \\
144\end{array}$ & $\begin{array}{r}\text { Percent } \\
+5 \\
+13 \\
+6 \\
+16\end{array}$ \\
\hline
\end{tabular}

If there is a thick copper layer in the composite coating, the calibration curve for nickel will give too high a result, and the curve for nonmagnetic coatings will give too low a result. However, the latter curve serves to give a minimum thickness for the deposit, and may be useful in works control, especially if the approximate ratio of the two metals is known.

\section{TYPICAL RESULTS}

The thickness of coatings on a number of commercial articles was measured magnetically, and the results were checked either with a microscope or by stripping. Microscopic measurements were made at the same points as the magnetic measurements. Samples for stripping were cut from the central portion of the specimen, so that the area tested would be fairly uniform in thickness. The average of a number of magnetic measurements on the sample was compared with the average thickness determined by stripping the same sample.

Table 2 summarizes the results of measurements on about 50 commercially plated articles. Those coatings that were not smooth were measured both before and after burnishing. In nearly all cases the burnishing gave more accurate results in addition to improving the reproducibility of the readings. The average error of the method is about \pm 10 percent for coatings thicker than 0.0002 in. $(0.005 \mathrm{~mm})$. Measurements of electrodeposited coatings of good quality and of smooth painted or enameled surfaces are generally satisfactory. Measurements on galvanized sheet were about 10 percent low, perhaps because of the presence of zinc-iron alloys. Results on tin plate are about 25 percent low, but all the coatings tested were very thin, for example, only $0.0001 \mathrm{in}$. $(0.0025 \mathrm{~mm})$ in thickness. If measurements on tin plate are consistently low, an appropriate curve can be based on calibration with similar coatings. The low results may be due to the formation of an alloy layer. ${ }^{9}$

' E. F. Kohman and N. H. Sanborn. Ind. Eng. Chem. 19, 514 (1927). 
TABLE 2.-Thickness of commercial coatings

\begin{tabular}{|c|c|c|c|c|c|c|c|}
\hline \multirow{3}{*}{ Metal } & \multirow{3}{*}{ Process } & \multirow{3}{*}{ Article } & \multicolumn{3}{|c|}{$\begin{array}{l}\text { Average thickness in } \\
\text { hundred-thousandths } \\
\text { inch }\end{array}$} & \multicolumn{2}{|c|}{$\begin{array}{l}\text { Error of mag- } \\
\text { netic method }\end{array}$} \\
\hline & & & \multirow{2}{*}{$\begin{array}{l}\text { Strip- } \\
\text { ping }\end{array}$} & \multicolumn{2}{|c|}{ Magnetic } & \multirow{2}{*}{$\begin{array}{l}\text { Unbur- } \\
\text { nished }\end{array}$} & \multirow{2}{*}{$\begin{array}{l}\text { Bur- } \\
\text { nished }\end{array}$} \\
\hline & & & & $\begin{array}{l}\text { Unbur- } \\
\text { nished }\end{array}$ & $\begin{array}{c}\text { Bur- } \\
\text { nished }\end{array}$ & & \\
\hline 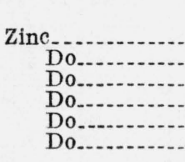 & 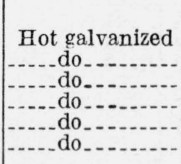 & 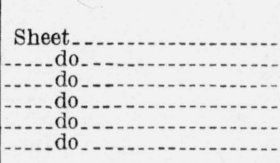 & $\begin{array}{l}116 \\
132 \\
104 \\
139 \\
114 \\
129\end{array}$ & $\begin{array}{r}105 \\
120 \\
85 \\
121 \\
115 \\
127\end{array}$ & $\begin{array}{r}-r \\
111 \\
124\end{array}$ & $\begin{array}{r}\text { Percent } \\
-10 \\
-9 \\
-18 \\
-13 \\
+1 \\
-2\end{array}$ & $\begin{array}{r}\text { Percent } \\
-3 \\
-4\end{array}$ \\
\hline $\begin{array}{l}\text { Do } \\
\text { Do } \\
\text { Do } \\
\text { Do } 0 \ldots \ldots \ldots \\
\text { Do }\end{array}$ & 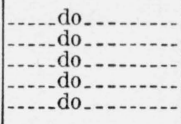 & $\begin{array}{l}\text { Pipes } \\
\text { Conduit boxes. }\end{array}$ & $\begin{array}{l}720 \\
174 \\
312 \\
338 \\
465\end{array}$ & $\begin{array}{l}630 \\
155 \\
250 \\
310 \\
443\end{array}$ & 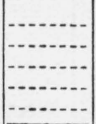 & $\begin{array}{r}-13 \\
-11 \\
-20 \\
-8 \\
-5\end{array}$ & 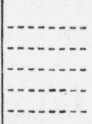 \\
\hline $\begin{array}{l}\text { A verage } \\
\text { error. }\end{array}$ & & & & & & -10 & \\
\hline Do............. & Sherardized...- & (- & 56 & 58 & & +4 & ... \\
\hline 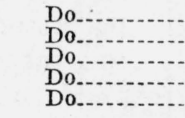 & 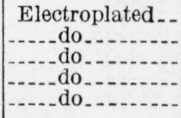 & $\begin{array}{l}\text { Lock-arm } \\
\text { Wire, } 0.09 \text { inch diameter.- } \\
\text { BX cable. } \\
\text { Stamping.... }\end{array}$ & $\begin{array}{r}18 \\
222 \\
42 \\
43 \\
13\end{array}$ & $\begin{array}{r}21 \\
230 \\
50 \\
48 \\
14\end{array}$ & $\begin{array}{r}16 \\
45 \\
45 \\
14\end{array}$ & $\begin{array}{r}+17 \\
+4 \\
+19 \\
+12 \\
+7\end{array}$ & $\begin{array}{r}-11 \\
+7 \\
+5 \\
+7\end{array}$ \\
\hline $\begin{array}{l}\text { Do } \\
\text { Do } \\
\text { Do } \\
\text { Do } 0 \text { Do }\end{array}$ & \begin{tabular}{|l}
$\ldots$ do \\
$-{ }_{2}$
\end{tabular} & 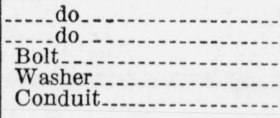 & $\begin{array}{r}15 \\
15 \\
17 \\
9 \\
152\end{array}$ & $\begin{array}{r}16 \\
18 \\
15 \\
9 \\
152\end{array}$ & $\begin{array}{r}14 \\
15 \\
12 \\
7 \\
-\end{array}$ & $\begin{array}{r}-7 \\
+20 \\
-12 \\
0 \\
0\end{array}$ & $\begin{array}{r}-7 \\
0 \\
-29 \\
-19 \\
\end{array}$ \\
\hline 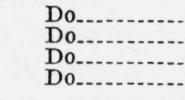 & \begin{tabular}{|l} 
\\
$-{ }_{-1}$ do
\end{tabular} & 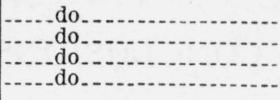 & $\begin{array}{r}167 \\
115 \\
77 \\
115\end{array}$ & $\begin{array}{r}165 \\
122 \\
71 \\
122\end{array}$ & $\begin{array}{r}74 \\
122\end{array}$ & $\begin{array}{l}-1 \\
+6 \\
+8 \\
+6\end{array}$ & $\begin{array}{r}+4 \\
+6\end{array}$ \\
\hline $\begin{array}{l}\text { A verage } \\
\text { error. }\end{array}$ & & & & & & \pm 9 & \pm 9 \\
\hline $\begin{array}{l}\text { Cadmium } \\
\text { Do } \\
\text { Do } \\
\text { Do } \\
\text { Do }\end{array}$ & 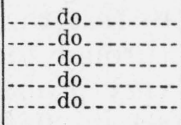 & 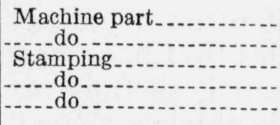 & $\begin{array}{r}16 \\
8.2 \\
8.2 \\
7.2 \\
24\end{array}$ & $\begin{array}{r}21.5 \\
9.0 \\
7.0 \\
7.6 \\
27\end{array}$ & $\begin{array}{r}19.2 \\
8.0 \\
25\end{array}$ & $\begin{array}{r}+34 \\
+10 \\
-15 \\
+6 \\
+13\end{array}$ & \begin{tabular}{r}
+20 \\
-3 \\
\hdashline 5 \\
+5
\end{tabular} \\
\hline $\begin{array}{c}\text { A verage } \\
\text { error. }\end{array}$ & & -2 & & $\ldots$ & - & \pm 16 & \pm 9 \\
\hline Chromium & ......do.......... & AES specimens & 24 & 24 & & 0 & \\
\hline Copper & ...... do & - do & 47 & 52 & 48.5 & +10 & +3 \\
\hline $\begin{array}{l}\text { Terne plate } \\
\text { Do } \\
\text { Do } \\
\text { Do }\end{array}$ & \begin{tabular}{|l} 
Hot-dipped.... \\
$-d 0_{-}$
\end{tabular} & $\begin{array}{l}\text { Sheet, thick. } 0.009 \text { in } \\
\text { Sheet, thick. } .015 \text { in... } \\
\text { Sheet, thick. } .011 \text { in } \\
\text { Sheet, thick. } \\
\text { She in }\end{array}$ & $\begin{array}{l}6.5 \\
93 \\
70 \\
63\end{array}$ & $\begin{array}{l}6.5 \\
94 \\
64 \\
62\end{array}$ & $\begin{array}{l}58 \\
64\end{array}$ & $\begin{array}{l}+2 \\
+1 \\
-9 \\
-2\end{array}$ & $\begin{array}{r}-17 \\
+2\end{array}$ \\
\hline $\begin{array}{l}\text { A verage } \\
\text { error. }\end{array}$ & & & & & & \pm 4 & $\ldots$ \\
\hline $\begin{array}{l}\text { Do } \\
\text { Do } \\
\text { Do } \\
\text { Do }\end{array}$ & 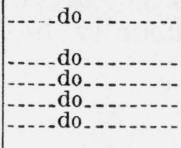 & $\begin{array}{l}\text { Tinplate sheet, } 0.010 \\
\text { thick. } \\
\text { do }\end{array}$ & $\begin{array}{r}11.2 \\
12.3 \\
7.5 \\
11.0 \\
7.1\end{array}$ & $\begin{array}{l}8 \\
8 \\
5.6 \\
9.0 \\
6.3\end{array}$ & 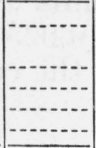 & $\begin{array}{l}-29 \\
-35 \\
-25 \\
-18 \\
-11\end{array}$ & 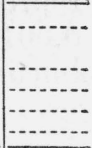 \\
\hline $\begin{array}{l}\text { A verage } \\
\text { error. }\end{array}$ & - & & & & & -24 & \\
\hline
\end{tabular}


TABLE 2.-Thickness of commercial coatings-Continued

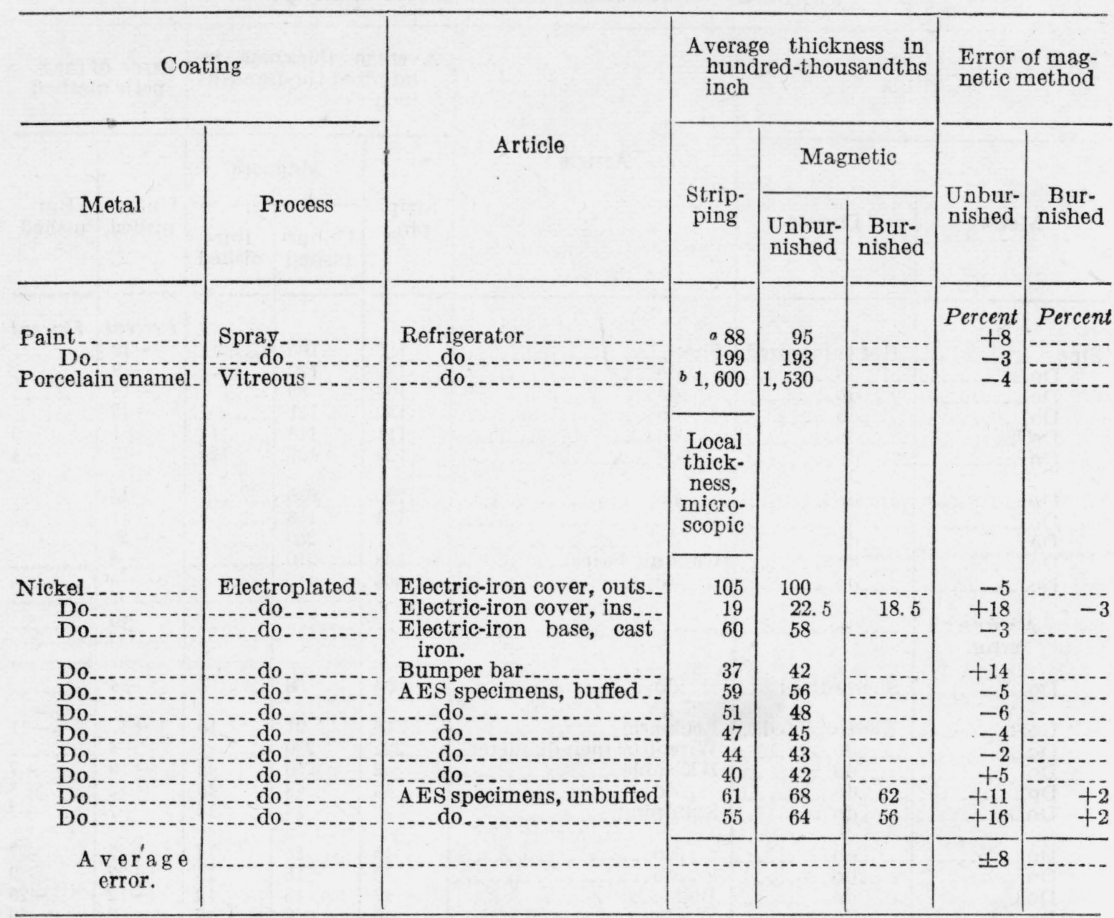

a Thickness by chord method.

$b$ Thickness by micrometer.

\section{CONCLUSIONS}

The magnetic method has been shown to be accurate enough for most commercial requirements. In most cases the method is nondestructive because it is not often necessary to test the base metal. The steel base metal of articles that have been through forming operations usually need not be tested, as they are very probably made of mild steel. If the coating is thicker than $0.001 \mathrm{in}$. $(0.025 \mathrm{~mm})$ the base metal need not be tested, since the calibration curves for thick coatings on many ferrous metals tend to approach each other. Therefore, a single calibration curve for nonmagnetic coatings on mild steel will fill the majority of needs. In plant control the magnetic properties of the base metal should be determined before plating.

Polished nickel coatings up to 0.001 in. in thickness can be measured (with an appropriate calibration curve) with about the same degree of accuracy as nonmagnetic coatings. On rough coatings, lack of reproducibility of measurements is serious for coatings thinner than $0.001 \mathrm{in}$. $(0.025 \mathrm{~mm})$. This difficulty can usually be removed by burnishing the coating before testing.

The author acknowledges the advice and assistance received from R. L. Sanford and W. Blum in this investigation.

Washington, January 18, 1938. 